\title{
Water access and sustainable rural livelihoods: A case of Elementaita Division in Nakuru County, Kenya
}

\author{
Cherutich Jonah $^{1}$, Timothy Maitho ${ }^{2}$, Quinter Omware ${ }^{1}$ \\ ${ }^{1}$ Department of Education and External studies, University of Nairobi, Nairobi, Kenya \\ ${ }^{2}$ Department of Public Health, Pharmacology and Toxicology, University of Nairobi, Nairobi, Kenya
}

Email address:

kamatiw@gmail.com (K. J. Cherutich),tmaitho@uonbi.ac.ke (T. Maitho), qokeyo@gmail.com (Q. Omware)

\section{To cite this article:}

Cherutich Jonah, Timothy Maitho, Quinter Omware. Water Access and Sustainable Rural Livelihoods: A Case of Elementaita Division in Nakuru County, Kenya. International Journal of Science, Technology and Society. Vol. 3, No. 1, 2015, pp. 9-23.

doi: $10.11648 /$ j.ijsts.20150301.12

\begin{abstract}
This study assessed water factors that impact sustainable rural livelihoods in Elementaita Division, Nakuru County. Problem of water access remains a multi-million challenge for families in rural areas and this had to be explained in scientific research through assessing water issues that affect the livelihoods. Households remain far from water projects despite interventions that governments, NGOs and other agencies have put in place. The study had the following objectives; assess water access factors and its impact on sustainable rural livelihoods, evaluate management of water projects and determine how it impacts on sustainable livelihoods and to determine how socio-economic factors of water impact rural livelihoods in Elementaita Division. The study used sustainable livelihood framework in its analysis and establishing what areas of interventions would be considered for the study. This includes looking at assets, capital, livelihood strategies, institutional processes and vulnerability context. This was a descriptive survey and questionnaires were generated on related areas of study. Sampling for household was carried out through systematic sampling. The study targeted a sample 195 household heads, 1 water users association also a Key Informant Interview (KII) was carried out with District Water Officer (DWO) and District Public Health Officer (DPHO). Data was carried collected using questionnaires, interviews and supplemented through secondary data. Data was analysed using inferential statistics by use of descriptive statistics. The findings were presented in tables using tables. From the findings water availability, quality and affordability determine the level of households assets in the community thereby impact negatively or positively. Over $98 \%$ of the respondents reported that children walk long distances or do not attend school in order to fetch water for the households, this impact negatively on their mental and physical development as well as their education. There is need to carry out awareness on the implication of using water of poor quality in the community as it may have adverse health effects on the lives of the community. Increasing awareness levels on rain water harvesting by the community need to be enhanced to improve on quality of water. Parents should also ensure that their children access education and not engage in child labour. The findings and recommendations of the study are important to Ministry of Water, researchers, all stakeholders and the community of Elementaita Division and Nakuru County in enhancing water access and addressing some of the challenges identified.
\end{abstract}

Keywords: Water Access, Sustainable Rural Livelihoods, Elementaita Division

\section{Introduction}

According to United Nations Development Programme (UNDP), (2006) report, people need water and sanitation to sustain their health and maintain their dignity. The report further states that water beyond the household sustains ecological systems and provides input into the production systems that maintain livelihoods. This means that water permeates all aspects of human development and lack of its access at household level or for production results to peoples' choices and freedoms curtailed by ill health, poverty and vulnerability.

The same UNDP report further reveals that globally an estimated 1.1 billion people in developing countries have inadequate access to water and 2.6 billion people of out the 6 billion lack basic sanitation. The above estimates concur 
with findings by World Bank, (2010) report which showed that water is a scarce resource with multiple interwoven uses that range from drinking water, energy, irrigation among others. The report further states that, more than one-sixth of the Worlds' population does not have access to safe drinking water, with $80 \%$ living in rural areas thus access to water cannot not be guaranteed globally.

UNDP, (2010) report developed three dimensions of Human Development Index (HDI); health, education and income. Of these dimensions highlighted in the report access to water by people may improve or reduce its severity. Women and young girls carry a double burden of disadvantages, since they are the ones who sacrifice time and their education to collect water UNDP, (2006) report. The report further states that there is more water in the world for domestic purposes, for agriculture and for industry. The problem is that some people notably the poor are systematically excluded from access by their poverty, by their limited legal rights or by public policies that limit access to the infrastructure that provide water for life and for livelihoods.

According to the recent progress report by the Joint Monitoring Programme WHO/UNICEF, (2010), global improved drinking water coverage increased from $77 \%$ to $87 \%$. However, the developing world including sub Saharan Africa continue to lag behind developed nations in their progress towards meetings the water related Millennium Development Goals (MDGs) WHO/UNICEF, (2008), WHO/UNICEF, (2010). Based on WHO/UNICEF, (2008) report, one of the most important measure to spur economic growth, reduce poverty as well improve public health is universal access to and use of clean potable water and sanitation supplies. Pruss-Ustan, (2008) found out that nearly $10 \%$ of total burden of diseases worldwide can be attributed to unsafe water, sanitation and hygiene, and the associated disease claim 3.6 million lives annually. As Bartram, (2005) says that access to improved water and sanitation is important because it acts as the foundation for healthy communities, and results in significant health, economic and social gains.

\subsection{Statement of the Problem}

Owing to the myriad challenges associated with rural communities accessing water, the researcher developed the topic to ascertain the impact of water access on rural livelihoods. According to Bauman, (2005) an estimated 35\% of rural water supplies in sub-Saharan Africa are nonfunctional an indication that peoples' livelihoods are being jeopardized. This reduces several households into seeking mitigating measures that would resort to high vulnerability.

According to KNWRMS, (2006), Kenya is classified as a water scarce country with $647 \mathrm{~m} 3$ per capita per annum. Kenya is categorized as a water scarce country because it falls short of 1,000 $\mathrm{m} 3$ per capita per annum benchmarked by UN. According to KIHBS, (2006) 57\% of households in Kenya access safe drinking water sources, $82 \%$ in urban setup and $48.0 \%$ in rural areas. The current situation of water shortage in Elementaita Division is wanting, several projects that were initiated Agricultural Development Corporation in 1980s were vandalized by people were resettled in the farm. Eight boreholes that were functional during the ADC operation, remains non-functional with only one functional. About 10,000 kilometres pipeline remains in sorry state as the inhabitants sold most of the steel pipes as scrub metals. There is also a noted depletion of forest cover in water catchment areas.

Connections of water point to households in Africa remain low. This limits access of households to water. When households are not connected, they have limited options and therefore impact negatively on their livelihoods. This means that these households may collect water from untreated water sources or purchase water from middle persons/vendors who overcharge the prices. Through this water becomes expensive and most households spend millions of shillings to buy water which would have been less costly to them UNDP, (2006).

Onjala, (2002) confirms that a large number of households are still far from water points. He further says that the level of coverage goes down as low as $20 \%$ during dry season when seasonal water sources dry up making distances to water long and often exceeding 5 kilometers.

KNDHS, (2009) reveals that increasing access to improved drinking water is one of the millennium Development Goals (MDGs) that Kenya along with other nations worldwide has adopted United Nations General Assembly (2001). The KNDHS report further says that lack of access to water source may limit the quantity of suitable drinking water sources available for use at household.

Several water projects have failed not because of funding but because of systems, policies as well management related factors coupled with socio-economic issues that have de-motivated sustainability of water projects in Rural Kenya. There are several non-functional water projects across the country that is in dire need of evaluation to ascertain what may have caused their current state. These calls for conclusive and well researched study that will enable government, development agencies and well as other relevant and interested groups to analyse and synthesize information that will be aimed at addressing the root causes of these endemic challenges that affect the water sector. The importance of this study is aimed at furnishing with researchable data that will catapult economic stimulus as well continuity of water projects in communities and thereby increase functionality of water projects in Rural Kenya. This study therefore, seeks to assess the impact of water access on sustainable rural livelihoods.

\subsection{Purpose of the Study}

The study aimed at assessing the impact of water access on rural livelihoods in Elementaita Division, Nakuru County, Kenya.

\subsection{Objectives of the Study}

The objectives of the study were: 
- To assess physical factors and its impacts on sustainable rural livelihoods in Elementaita Division.

- To evaluate management of water projects and determine how it impacts on sustainable livelihoods in Elementaita Division.

- To determine how socio-economic factors of water impact on rural livelihoods in Elementaita Division.

\subsection{Research Questions}

The research questions were:

1. Does what extent does physical factors of water impact on sustainable livelihoods in Elementaita Division?

1.1 To what extent does availability of water impact on sustainable rural livelihoods in Elementaita Division?

1.2. Do what extent does water quality impact on sustainable rural livelihood in Elementaita Division?

1.3. To determine how water affordability impact on sustainable rural livelihoods in Elementaita Division?

1.4. How does distance from a water point and time taken to collect water impact on sustainable rural livelihoods in Elementaita Division?

2. Does management of water projects impact on sustainable rural livelihoods?

2.1. What is the level of training of water technicians in Elementaita Division?

2.2. To what extent does decision making of water users' impact on sustainable rural livelihoods in Elementaita Division?

2.3. To what extend does gender in management of water impact on sustainable rural livelihoods in Elementaita Division?

2.4. How does operations and maintenance of water projects impact on sustainable rural livelihoods in Elementaita Division?

3. Do socio-economic factors of water affect sustainable rural livelihoods?

3.1. How does water scarcity impact on sustainable rural livelihoods in Elementaita Division?

3.2. How does water use impact on sustainable rural livelihood in Elementaita Division?

\subsection{Significance of the Study}

The findings of the study once shared will be useful for NGOs, government of Kenya and other researchers in the field of water. As Montogomery, (2007) said that the usefulness of information gathered ensured that there is gaining of a better understanding of economic, social and technical factors on sustainable livelihoods allows interventions to be tailored to fit the needs and conditions of sub Saharan Africa, at the regional, national and local levels.

The findings will also be useful to policy makers and institutions of learning and management to be able to manage water projects in sustainable manner.

\section{Literature Review}

\subsection{Sustainable Rural Livelihoods}

In a classic 1992 paper, Sustainable Rural Livelihoods: Practical concepts for the 21 st Century, Robert Chambers and Gordon Conway proposed a definition of sustainable livelihood:

"A livelihood comprises of capabilities, assets (stores, resources, claims and access) and activities required for a means of living; a livelihood is sustainable which can cope with and recover from stress and shocks, maintains or enhance its capabilities and assets, and provide sustainable livelihood opportunities for the next generation; and which contributes net benefits to other livelihoods at the local and global levels and in the short and long term".

Sustainable livelihoods approaches has increasingly been developed and adopted by many development institutions as a means of analysis and of action by depicting processes through which individuals and households use all or part of it in their reach to make their living. Department for International Development (DFID's) Sustainable Livelihoods Cooperative for Assistance and Relief Everywhere (CARE's) Household Livelihood Security and United Nations Development Programme (UNDP) Human Development are examples of agencies implementing through Sustainable Livelihood Approaches, Moriatry. P. et al (2004).

\subsubsection{Sustainable Livelihood Framework}

Scoones, (1998) elaborated three elements of Livelihoods Framework: Livelihood Resources, Livelihood Strategies and Institutional Processes and Organizational studies.

\subsubsection{Livelihood Resources}

Scoones, (2009) defines livelihood resources as the basic material and social, tangible and intangible assets that people use for constructing their livelihoods. These livelihoods resources are conceptualized as different types of 'capital' to stress their role as a resource base. These resources or assets are natural, economic or financial, human and social capital. Another capital asset that was added by DFID was physical capital.

Natural capital refers to the natural resource stocks like water, soil and air among others and environmental services such as hydrological cycle. These are important because livelihoods are derived from it. Economic or financial capital refers to capital base including infrastructure, production equipment and technologies that are critical in pursuit of any livelihood strategy. Human capital refers to skills, knowledge, ability to labour and good health and it is important for pursuit of different livelihood strategies. Social capital refer to social resources i.e. networks, social claims, relations, affiliations and associations upon which people draw when pursuing different strategies. Grey-Gardner, (2008) summarized the livelihood assets as follows: Natural: water availability, quantity and quality. Human: skills knowledge, ability and health. Physical: water supply infrastructure, equipment, maintenance materials (including tools). Financial: 
financial resources including savings, grants, pensions, loans. Social: quality of social networks and relationships.

\subsubsection{Livelihood Strategies}

DFID, (1999) reported that in order to have improved rural livelihoods; structures and processes need to be transformed. These include; initiating changes in local institutions, reforming institutions through change of culture, norms, that limit access to the livelihood resources and assets. Another critical dimension is reforming communities through training on existing policies that undermine their existence as well as pass more information to the community members to be able to articulate issues that affect them. Another strategy may be carrying out community capacity building on areas of access to be able to reach many people. This means that certain members of the community are given priority to be able make and participate in decision-making processes to be able to address issues affecting the concerned community.

\subsubsection{Institutional Processes and Organizational Studies}

In order to be able to understand institutional processes, DFID, (1999) came up with four areas of focus namely: policies- which refers to those issues that inform development and provide framework for actions of public sectors, institutions refers to markets, institutions that regulate access to assets while culture refers to societal norms and beliefs. Power relations refer to age and gender of the people involved in the organization. Leach et al, (1999), further developed the concept of livelihoods to include formal and informal institutions and the distribution of power in understanding how people gain access to and control over assets and utilize them in pursuit of livelihoods.

\subsubsection{Vulnerability Context}

Carney, (1998) defines vulnerability context to include natural and human-led trends and shocks. Nicol, (2000) says that in the Sustainable Livelihood framework in water sector is critical in getting an understanding of vulnerability context within which rural people gain and secure access to water resources. He further says that access and water security are determinants of local level processes including norms and customs, local property rights regimes and local economic factors related to water issues.

Different context present different levels of risk in securing access to suppliers i.e a number of factors will affect the risk profile including context (urban or rural); topographical factors; the transparency of government, availability of local private sector companies and the channels of communication through which demands can be expressed, Nicol, (2000).

Vulnerability not only posed by physical factors but also the risk and vulnerability to livelihoods through unstable social, physical and political environments which see voting controlled through patron-client networks, and local processes of decentralization captured by elites. Social vulnerability may relate to fragmentation within communities and households caused by adverse social processes, age-sex composition of households and communities and the ability to overcome challenges posed by heterogeneity and extremism.
Political vulnerability refers to arbitrary exercise of power by political authority and the link between political change and decision-making regarding resource access, Nicol, (2000). As Nicol further says that when water is available and improved greater demand arises and therefore may affect demand for labour is increased and therefore children spend more time collecting water. This may affect their physical development as well as academic performance. However, less access may also affect negatively on children and women walking long distances in search for water for the household.

Vulnerability context impacts livelihood assets and vice versa. Policies and institutions as well as process have a two-way impact. It is important to note that when there are favourable government policies and processes there are reduced shocks and negative effects on people's livelihoods. Any deprivation of any of the livelihood assets/capital may have a negative impact on the vulnerabilities of households and communities, Twigg, (2001).

In rural areas in general, water plays a critical role. Access to a reliable supply of water allows people to expand their livelihoods, increase productivity and reduce the risks associated with the vulnerability. The factors that make up the vulnerability context are important because they have a direct impact upon people's assets and the livelihood options that are open to them. These categories include: trends, shocks and seasonality. Trends are long term and usually large scale. These include population trends, resource trends, economic trends, trends in governance and politics, and technological trends. Shocks include human health shocks, natural shocks, and economic shocks. They can destroy assets directly. They can also force people to dispose of assets as part of coping strategies. Resilience to external shocks and stresses is important factor in livelihood sustainability. Seasonality is expressed through seasonal shifts in prices, production, food availability, employment opportunities and health. These are one of the greatest and most enduring of hardship for poor people, Twigg, (2001).

\subsection{Physical Factors of Water Access Factors and Sustainable Livelihoods}

According to Human Development Report (HDR) (2006), the UN Committee on Economic, Social and Cultural declared that water is a human right that each one is entitled to sufficient, safe, acceptable, physically accessible and affordable for personal and domestic use. These five core issues represent the foundations of water security. Yet they are widely violated. The report further says that poor households are less likely to get their water from a variety of improved sources. In Dar- es Salaam-Tanzania or Ouagadougou-Burkina Faso fewer than 30\% of households are connected.

According to World Bank, (2009) rural areas perform consistently worse than urban areas on water access. $38 \%$ to $52 \%$ have easy access to safe water as compared with $59 \%$ to $83 \%$ in urban areas. UNFPA, (2003) report that in Sub Saharan Africa, there are 10 countries including; Angola, Chad, Democratic Republic of Congo, Eritrea, Ethiopia, 
Guinea, Madagascar, Rwanda, Sierra Leone and Kenya are the most vulnerable in terms of access to safe water as well as hunger. The report further reveals that between a third and half of the populations have access to safe water and over a third of the population are undernourished.

UNDP, (2006) report that water access fell short by five percent since 1990 due to shortage of adequate funding to repair or replace rapidly aging infrastructure. However, this coupled with other issues of management and post project implementation through tariffs may improve the operations and maintenance of water systems to meet the needs of communities. About $49 \%$ of rural communities had access to water falling short of the target of $85 \%$ as stipulated by the millennium development goals targets.

According to SIWI, (2004) report some of the benefits associated with improved water access include but not limited to; improved human health, improved education, improved food security and food production. These cannot be achieved easily if good water management practices are not put in place to ensure that the benefits of water last longer. This means that business plans are developed to ensure that communities manage and utilize water in an effective and efficient way.

There is need to link other factors together to ascertain the level of impact that water access has on sustainable rural livelihoods. This can involve looking at how water availability, distance to collect water, affordability and management of water projects and their corresponding challenges affect rural livelihoods. This will involve having a look at the interdependence and interlink of the factors.

\subsubsection{Water Availability and Sustainable Rural Livelihoods}

In order to get an understanding of water availability, the study relies heavily on the work of Carlevaro and Gonzalez, (2011) that identified sources of water and categorized in three main types; rainwater, surface water (river, streams, lakes and ground water. Out of these three sources, groundwater is assumed to be of good quality however, this is an assumption that is not always correct.

The selection of a water source will depend on quality, quantity, of the water, costs of development, operation, funds available, and distance from the community it serves DFID, (2011). All these factors may affect negatively or positively on the livelihoods of households while posing vulnerabilities and risks if some issues are compromised.

OCHA, (2010) reveals that in a provisional 2010 Sphere project standards for water use it was projected that the average per capita water consumption be at least 15 litres per person perday that equals to 5475 litres annually. Availability of water sources remain a daunting tasks for communities and families.

Availability of water poses several challenges to households and communities. In areas where water is not available, women and children travel tens of kilometres to fetch water. This is seen through queues in water points during dry seasons. In concluding remarks by DFID, (2002) report, the availability of a good quality water source close to home has numerous benefits especially in terms of human wealth, with subsequent linkages to all other dimensions of livelihoods.

\subsubsection{Sources of Water}

Rain Water Harvesting and Sustainable Rural Livelihoods

It is an ancient technology that has a proven record of providing water next to the house for domestic use and on a larger scale for economic use by increasing the productivity of arable lands and watering livestock, Smet, (2005). Families that do not have the technology to utilize the water may not be able to harvest the water. This is because it needs guidance on the design, construction and maintenance of rainwater catchments systems that may cost more than the facility could afford, Petersen and Gould, (1999). Sometimes the rainwater may carry pollutants that it picks from the atmosphere and therefore need technical skills to be able to discard the first flush of water from the catchments surface, Pacey and Cullis, (1986).

A family with stable financial capital with an eager attitude towards rainwater harvesting may set up structures that are going to improve on the livelihoods and reduces stresses associated with lack of water for the household or for livestock or agriculture.

\subsubsection{Water Quality and Sustainable Rural Livelihoods}

Access to safe drinking water is one of the Millennium Development Goals (MDGs) agreed upon by the World's leaders in the United Nations Millennium Summit in 2000. The MDG drinking water target is to halve by 2015 the proportion of people without sustainable access to safe drinking water, WHO, (2011). The report further states that access to safe drinking water is an element of sustainable development and is central to the goal of poverty reduction. Lack of quality water means a lot to families, communities and children. According to WHO, (2002)-report lack of access to safe water, basic sanitation and good hygiene practices is the third most significant risk factor for poor health in developing countries with high mortality rate. WHO, (2004) further reports that diarrhoeal diseases for instance is widely recognized as the principal result of inadequate water, sanitation and hygiene. The report further reveals that 1.8 million people die every year from diarrhoeal disease, $90 \%$ of whom are children below the age of 5. Most people in Sub Saharan Africa spent at least a third of their income on treatment of water related diseases like malaria and diarrhoea, SIWI, (2004). SIWI report further states that, women in Sub Saharan Africa spend up to 6 hours a day on water collection chores. The time spend could be utilized for other productive duties such as child care, harvesting, or any other income generating activity that the household would utilize for improving its livelihood and living standards.

According to UN-Water, (2007) attribute water scarcity often creates a question of water quality, this result from environmental pollution and using un-protected water points. The report further asserts that water and health are intimately interlinked. Water conveys pathogens to people and provide the habitat for vector and intermediate hosts of pathogens. Shortage of water and inadequate sanitation may limit the 
ability of families to cope with some threats that may lead to infection and illnesses. Disease associated with water affect the poor with greater margins as compared to rich nations with a burden of ill health that creates a vicious cycle of poverty and sickness, UN-Water, (2007). Such families and communities may not be able to carry out their tasks effectively due to several hours or even days supporting sick people or relatives. This limits their socio-economic productivity.

Vulnerable communities are disproportionately affected by poor water quality. These communities include those that live near water ways of compromised quality. In order to mitigate on the risks of diseases suffered by communities, families and communities can mobilize towards improved drinking water facilities UN-Water, (2007).

\subsubsection{Water Affordability and Sustainable Rural Livelihoods}

UWAZI report, (2007) says that inequitable investment and poor maintenance result in affordable water. Supply of water from water points and through water, pipelines to kiosk is unreliable due to artificially created water shortages by cartels. These cartels create a temporary shortage by either blocking on the water pipelines on destroying intakes to create a water problem. As a result, those who can least afford to pay, pay high prices and persistently have the worst access to safe water.

\subsubsection{Distance and Time Spend to Water Points and Sustainable Rural Livelihoods}

Inadequate water infrastructure can create multiplier risks in rural areas. Several hours are wasted when women and children spend more time to fetch water for domestic use in walking for long distances to water points. Another critical aspect to this challenge is the time used to queue on water points that may take over 4 hours. This coupled with low inflow of water due unimproved water source. Most water sources are dilapidated state. The HDR (2006) argues that Kenya will need to increase the number of people with access to water by 11.6 million. This target is daunting but may be attainable.

OCHA, (2010) reported that as at 2010, 1.1 billion people lived more than one kilometre from their nearest safe water source. This number would be even worse with projections that more than 5 billion people of the world's population would be without access to water and sanitation by 2030 . UNFPA, (2002) report estimated that women in many developing countries walk for an average of about 6 kilometres each day to collect water. The report further states that water collection for domestic purposes is generally the responsibility of women and children. Therefore, availability of clean water to households reduces the women's workloads and hours spent in fetching water.

Based on UN, (2000) report showed that water collection times for villages in Kenya average just over 4 hours per day in dry season and 2 hours per day in wet season. The data also indicate times in the range of 4 to 6 hours per day in Botswana, Burkina Faso and Ivory Coast.

Women are exposed constantly to the risk of contraction of water-related diseases largely because of their role in collecting water, washing clothes, cleaning and cooking and in particular in rural areas performing day-to-day agricultural task. Carrying heavy water jars over long distances puts women's health at risk, particularly during pregnancy. Bearing heavy loads can result in premature birth, a prolapsed uterus, or back injuries, UNFPA, (2003).

UNDP, (2006) report states that for young girls, the lack of basic water and sanitation services translates into lost opportunities for education and associated opportunities for empowerment. The report further states, that the time burden for collecting and carrying water is one explanation for the very large gender gaps in school attendance in many countries. The report further identifies that Tanzania schools attendance levels $12 \%$ higher in homes 15 minutes or less from a water source that in homes an hour or more away. Young girls, particularly after puberty are also less likely to attend classes if the school does not have suitable hygiene facilities.

\subsection{Management of Water Projects and Sustainable Rural Livelihoods}

UNDP-World Bank, (2008) report in its Water and Sanitation decade reports, estimates that achieving lasting benefits from water supply interventions involves much more than building facilities. It must be focused on the importance of involving the community in all aspects of service delivery, use of appropriate technologies, and the role of governments as service promoter rather than provider. The report further revealed that governments have an assumption that communities somehow 'manage' their facilities but do not help build capacities nor have any commitment to do so. This leaves communities to design their own traditional approaches towards maintaining water systems. There is need to define the roles of community members in project planning, implementation, cost recovery, operations and maintenance (O \&M) and asset ownership that are poorly defined and communicated.

Haysom, (2006) reported that management of water projects encompasses among other critical elements, participation that is viewed as a tool for improving the efficiency of a project. It is also seen as a fundamental right that beneficiaries should have a say about interventions that affect their lives. Participation can take different forms including the initial expression of the demand for water, the selection of technology and its site, the provision of labour and local materials, a cash contribution to the project costs, the selection of the management type and even water tariff.

Management of water projects remains critical for its operationalization as well as continuity of the project. Most projects that are managed well outlive their functions. Haysom, (2006) proposes in his study on Tanzania water projects that there could be separation of roles as purchaser, service provider, regulator and asset holder to be able to meaningfully manage the water and be able to reach man people in rural communities.

According to E-Sadek, (2011) identified three levels of decisions and improvements that can be taken in management 
of water. The lowest level that this study will address is the user's level. This level includes; increasing users' awareness, applying water pricing and water saving technology would lead to improve in local water efficiency. With water shortages and grim future if the current trend continue, there would be a growing understanding that sustainable water management requires water governance, including integrated water resource management. Integrated water resource management coordinates the development and management of water, land and related resources. It seeks to maximize social and economic welfare in an equitable manner, to sustain ecosystems and bring together the technical, social and political spheres, WED, (1992).

\subsection{Socio-Economic Factors of Water Access and Sustainable Rural Livelihoods}

Overseas Development Institute (ODI), (2003) says that where women undertake most agricultural labour, productive impacts are significant. For households and economies relying on the sale of labour, the cost of losing a day's labour can be exceptionally high at particular times of the year. The opportunity cost of water collection can have social, economic dimensions. For example, when the burden of collecting water falls disproportionately on children, the result may be lost education, health and safety of children among other multiplier effects. Women and children collecting water at night may also injure themselves or even engage into circumstances that may erode their emotional wellbeing.

People suffering from water-related diseases occupy more than half of the world's hospital beds, Lenton et al, (2005).
Economically, improving water and sanitation services worldwide would have great benefit. It is estimated that each dollar invested in improving water and sanitation could yield \$3-34 depending on the region, and $\$ 7.3$ billion in health-related costs could be avoided each year, Lenton et al, (2005).

The issue of water pricing is a critical concern in the management of water projects. Under-pricing of water, which is practiced in most countries of Africa and Middle East, allows low-value users such as agriculture (which accounts for $88 \%$ of end users overall) to consume large qualities of water and use it wastefully. The result is depletion, degradation and physical and economic losses. Under-pricing also results in unreliable service, unwillingness to pay, and decline in capacity to provide services, (IDRC, 1996). The IDRC report further stated that apart from water pricing other factors such as complex social, cultural, political and economic factors impact availability, allocation and use of water.

\subsubsection{Water Use}

White et al, (1972) segregated water into the following uses: consumption, hygiene and amenities. Water for consumption refers to water content in beverages and food. Hygiene refers to the minimum water to wash one's body, clothes, utensils, food, clean the home, and for sanitation. Amenities refer to other uses which include bathing, watering gardens, washing cars. Through these categories, water utilized or consumed may vary from each item discussed that may cause a vulnerability to the household assets.

\subsubsection{Water and Food Security}

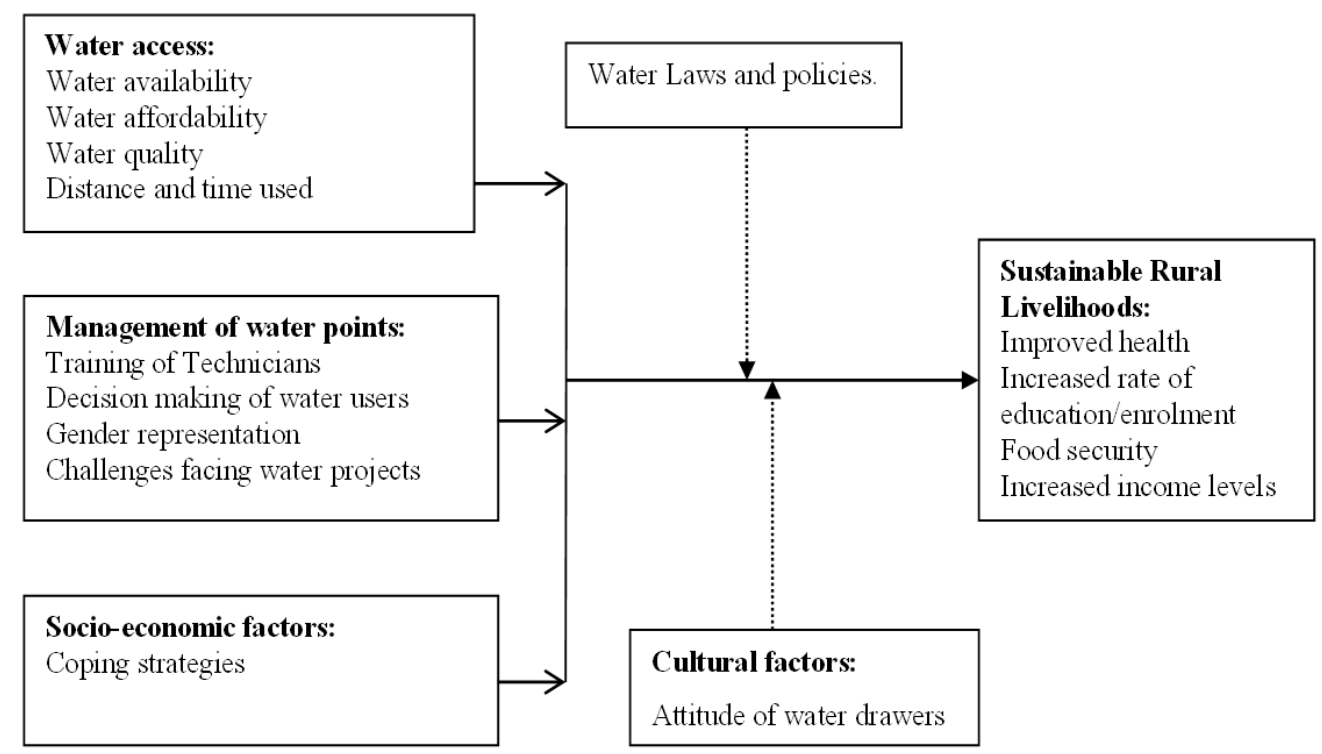

Figure 1. Conceptual Framework

DFID, (2002) reveals that food and water security are related and that food security is an outcome of a set of vulnerabilities, dependent on how people gain access to production and exchange of opportunities. This is impactd by the broad expenditure, in time, labour or money, invested by households in gaining access to water.
There are also important gender and age specific issues involved in the division of labour for water collection. In rural Africa, where most agricultural labour is undertaken by women, productive impacts can be significant. For households and economies relying on the sale of labour, the cost of losing a day's labour can be exceptionally high at particular times of 
the year ODI, (2002). A key question in water collection, therefore, concerns the opportunity cost of this time- within and between households, across seasons and between good and bad years.

The opportunity cost of water collection can be of social and economic dimensions. The burden of collecting water falls disproportionately on children; the result may be lost education. Other areas that may be affected include health, nutritional and safety dimensions, DFID, (2002).

In a study conducted by Roy et al, (2005) in the community of N'atipkong and Ngendui in Kenya, women reported spending an average of 3.5 hours each day collecting water during dry season and double that in wet seasons because of hillsides and slippery hills. The report further reveals that children also collect water particularly during weekends and take longer because they play at the water points and collect less water of about 10 litres instead of 20 litres, DFID, (2002).

\subsubsection{Assessing Cost-Effectiveness of Water}

In order to ascertain the cost effectiveness of water projects in rural areas a critical look at the economic assessment focused on time saving, health benefits that come from time freed by fewer episodes of ill-health; this means that time can be used for additional livelihood activities. The saved time may also be available for preventing premature deaths. This would also be used to mean that the number of days that a person is ill in a year is treated as days totally unavailable for any meaningful livelihood activities, DFID, (2011).

\subsubsection{Improved Drinking Water Source}

Improved drinking water source refers to one that is protected from contamination WHO/UNICEF, (2008). If water is collected from a safe source, unsafe handling or storage of water can contaminate water, making household water treatment an important means of ensuring safety, WHO/UNICEF, (2008). It is critical to note that peoples' basic standards can be satisfied if the round trip to the water source is 30 minutes or less, WHO/UNICEF, (2004). When families are able to collect water within the said requirements, time that is more meaningful would be used to carry out other development initiatives in the household and thereby improve on the livelihoods and eventually on the living standards of the family and community.

\subsection{Theoretical Framework}

\subsubsection{Roots of Livelihoods Thinking}

There were several cross-disciplinary research efforts that were made by researchers in earlier days which focused on household studies, villages, faming systems that have come to impact development studies and livelihoods thinking in modern society, Lipton and Moore, (1972). The issue of sustainable development came into force in 1990's into the development discourse. These were as a result of strategies aimed at reducing poverty, people centred approaches, and sustainability in the political arena and development theory and practice that resulted in the widespread adoption and adaptation of livelihood definitions, models, and frameworks,
Scoones, (2009).

Chambers and Conway, (1992) most often trace the explosion of livelihood research and literature to a working paper that emerged from the Institute of Development Studies in 1992, which sought to theoretically locate sustainable livelihoods within the actor-oriented approaches to development, the framework of environmental and social sustainability and the rhetoric of poverty reduction. The two researchers sought to diversify the definition to incorporate the narrowly conceptualizations of poverty as production, employment and poverty line thinking to include ideas of capability, assets and sustainability, WCED, (1987, Sen, (1987), Swift, (1989).

\subsubsection{Determinants of Livelihood}

There are numerous determinants of livelihood strategy. Many livelihoods are predetermined by accident of birth. These are referred as ascriptive for example in India children may be born on a caste with an assigned role as potters, shepherds or washer people. Many livelihoods are less singular or predetermined. Some people improvise livelihoods with degrees of desperation, what they do being largely determined by social, economic and ecological environment in which the find themselves. A person may also choose livelihoods especially through access to education or migration, Chambers et al, (1991).

\subsubsection{Components and Flows in a Livelihood}

Chambers and Conway, (1991) came up with four components of Sustainable Livelihoods namely; tangible assets (stores and resources), intangible assets (claims and access), and people and livelihood capabilities. Stores are tangible assets that include food stocks, stores of value such as gold, jewellery and woven textiles and cash savings in banks of thrift and credit schemes. Resources include land, water, trees, livestock, farm equipment and domestic utensils, Chambers et al, (1991).

\subsubsection{Rights Based Approach}

In 2002, following the World Summit on Sustainable Development in South Africa, a United Nations committee siding with those who objected to the privatization of water supplies declared that; "Water should be treated as a social and cultural good and not primarily as an economic commodity". Later, ECOSOC, the United Nations Committee on Economic, Cultural and Social Rights agreed on a general comment on water as a human right: "Water is fundamental to life and health. The human right to water is indispensable for leading a healthy life in human dignity. It is a pre-requisite to the realization of all other human rights." UNESCO, (2004).

In theory, the sustainable livelihoods frameworks and thinking offer a systematic, holistic, inter-sectoral, actor-oriented approach for understanding the lives of poor and marginalized people and creating links to macro level policy for poverty reduction. In practice from what researchers have carried SL approaches have proved useful for research, programmatic interventions and policies that have focused on poverty reduction, food security, tourism 
development, fisheries development and water sectors among others, Benneth, (2010).

\subsection{Conceptual Framework}

The study has identified independent variables which include; physical factors of water access that include- water availability, water affordability, water quality, distance and time taken to collect water. Another variable is management of water projects that is segregated into; training of technicians, level of decision making of water users and management and gender representation and challenges operations and maintenance of water projects. Another independent variable is socio-economic factors that includes; level of community relationships and water use.

The study also looked at the dependent variable-sustainable rural livelihoods. The variables studied included; improved health, increased rate of enrolment/education, food security, increased income level. On moderating variable it included water laws and policies while intervening variable was attitude of water drawers.

\section{Research Methodology}

\subsection{Research Design}

A descriptive survey was used in the study on assessing the impacts of water access, management, and socio-economic factors on sustainable livelihoods in rural areas. Mugenda and Mugenda, (2003) contend that the purpose of a descriptive research is to describe behaviours and characteristics. For the purposes of obtaining adequate and relevant information in a short time, the study used survey to collect the data.

\subsection{Target Population}

The target population was picked from household heads within Elementaita Division of Gilgil District. Elementaita Division has 45 villages and has four sub locations. Each of the sub locations were clustered and based on their population the villages were selected. Kong'asis sub location was represented by 5 villages, Kiambogo sub location 6 villages and Miti-Mingi sub location by 2 villages. In each of the sub locations, simple random sampling was carried out in picking the number of villages which was as follows, Kong'asis sub location- Olesirwa, Block D, Kapkures, Kong'asis and Kampi Turkana villages. In Kiambogo sub location, Kahuho, Kiambogo, Gituamba, Tee, Tangi Tano and Kahoroko Villages were selected. Finally in Miti-Mingi sub location, Kiptangwany and Munanda villages were selected. One water group was randomly selected among 10 Water Users Associations. Key informant Interviews were carried out with District Water Officer-Gilgil District and Public Health Officer- Elementaita Division. The area has 4546 households and 195 household heads were interviewed.

\subsection{Sampling Procedure}

According to Mugenda and Mugenda, (1999) where there is time and resources, a researcher may take a bigger sample. This means that there would be a higher level of confidence. They further add that if the target population is less than 10,000 the sample size would be calculated as follows:

$$
n=\frac{Z^{2} p q}{d^{2}}=\frac{(1.96)^{2}(0.5)(0.5)}{(0.07)^{2}}=196
$$

where;

$\mathrm{n}=$ the desired sample size

$\mathrm{Z}=$ the standard normal deviate at the required confidence level of $95 \%$.

$p=$ the proportion in the target population estimated to have characteristics being measured

$\mathrm{q}=1-\mathrm{p}$

$\mathrm{d}=$ the level of statistical significance set (confidence interval) of $7 \%$.

This sample size is close to the sample size proposed by Yamane, (1967) of 194 for a population of 4546 with precision levels of $\pm 7 \%$ in appendix 7 . Therefore a sample of 196 would be selected for the study. This was carried out through cluster sampling of sub locations and randomly selected villages. Systematic sampling was carried out for all the households in each of the villages.

Probability sampling was used collect data. Castillo, (2009) said that probability sampling is a sampling technique where the samples are gathered in a process that gives all the individuals in a population equal chances of being selected. Probability sampling allows subjects in a population to be randomly selected, so that each one of the stands an equal chance of being included in the study. The study also selected 1 water uses group for focus group discussion of the ten existing water groups.

\subsection{Data Collection Instruments}

Data was collected from households in Elementaita Division. Primary data was collected using structured questionnaires with both open and closed questions. The questionnaire was administered to the respondents by the researcher with the help of four research assistants. The data collection used a questionnaire because of it is a typical method through which descriptive data can be collected, Gay, (1981).

Focus group discussion is another method that was used to collect data from selected groups. This is because the groups have information that was important in addressing management challenges faced by water users and drawers. Focus group discussions have been found helpful in assessing needs, developing plans, testing new ideas or improving existing programmes, Krueger, (1988); Babbie, (1992). Focus group guides were developed to be used in the focus group discussion. A group of 6 ( 2 female and 4 male) committee members were interviewed.

Key Informant Interviews were carried out with Government of Kenya Ministries of Water and Irrigation and Public Health. This gave the report a technical look at issues affecting communities. 


\section{5 . Validity and Reliability of Instruments}

Validity determines whether the research truly measures that which it was intended to measure or how truthful the research results are, Joppe, (2000). In order to ascertain the extent of the research instruments, the researcher conducted a pre-test of 10 respondents from the sample to test the instrument. Mehrens, et al., (1987) refers face validity to whether the test looks valid "on the face of it." For content validity was used to check on word and phrases used in the questionnaire. Pre-test of the questionnaire was carried out to ensure that the content in the questionnaire remains unbiased.

Reliability refers to the extent to which results are consistent over time and an accurate representation of the total population under the study, Joppe, (2000). Kirk and Miller, (1986) came up with three types of reliability which relate to quantitative research as: (1)the degree to which a measurement, given repeatedly, remains the same, (2) the stability of a measurement over time; and (3) the similarity of measurement within a given period of time. Worthen et al (1993) defines reliability as a measure of how stable, dependable, trustworthy, and consistent a test is in measuring the same thing each time. During this study the researcher used 10 questionnaires to determine the effectiveness of the research instrument.

\subsection{Data Analysis Techniques}

Anderson and Poole, (2001) says that the researcher must be able to interpret the data reliably, once data has been collected. The data collected was analysed using descriptive statistics such as percentages, means scores, mode, and standard deviation. Both qualitative and quantitative data will be analysed and interpreted using descriptive statistics in order to address the research objectives. Data was keyed in Statistical Programme for Social Scientist (SPSS). Results will be presented in tables using percentages and frequencies to facilitate comparisons. Excel worksheet will be used for data analysis.

\section{Discussion}

\subsection{Physical Factors of Water Access}

The section has been divided into four areas of analysis namely, water availability, water quality, water affordability and distance and time taken to fetch water.

\subsubsection{Water Availability}

Table 4.1. Access by Respondents to Water Source

\begin{tabular}{lll}
\hline Description & Frequency & Percentage \\
\hline River & 13 & 6.7 \\
Pond & 9 & 4.6 \\
Borehole & 65 & 33.3 \\
Piped into dwelling & 5 & 2.6 \\
Public tap & 58 & 29.7 \\
Unprotected pan & 11 & 5.6 \\
Rainwater & 34 & 17.4 \\
Total & 195 & 100 \\
\hline
\end{tabular}

From the above presentation, majority of the respondents $33.3 \%$ accessed borehole for water while this was followed closely by public tap $(29.7 \%)$, Rainwater (17.4\%), River (6.7\%), Unprotected pan 5.6\%), pond (4.6\%) and piped into dwelling (2.6\%).

\subsubsection{Water Quality and Health of the Respondents}

The sub section discusses on the impact of water quality on health of the respondents with regard to water sources, its effects and its quality.

In order to ascertain the level of water quality of the water and its effects on the health of the respondents, questions were asked as in Table 4.2 (Whether they are affected by the water) and Table 4.3 (if they were affected, what were results).

Table 4.2. Distribution on whether they suffer from the water sourced

\begin{tabular}{ccc}
\hline Description & Frequency & Percentage \\
\hline YES & 113 & 57.9 \\
NO & 82 & 42.1 \\
Total & 195 & 100 \\
\hline
\end{tabular}

From the respondents interviewed, majority (57.9\%) reported being affected by the water whereas $42.1 \%$ of the respondents reported not to have suffered from the water. This was to the respondents practicing rain water harvesting, public tap and piped into dwelling.

From the results above, further discussion was looked into establishing of the $57 \%$ percent of the respondents what they were suffering from as presented in Table 4.3.

Table 4.3. Distribution of respondents who reported health problems

\begin{tabular}{lll}
\hline Description & Frequency & Percentage \\
\hline Fell sick (diarrhoea, dysentery, & 90 & 79.6 \\
amoebiasis) & 23 & 20.4 \\
Discoloured teeth & 113 & 100 \\
Total & & \\
\hline
\end{tabular}

From the above analysis, majority of the respondents $79.6 \%$ reported suffering from diarrhoea, dysentery and amoebiais after using the water while $20 \%$ of the respondents have their family members or themselves discoloured teeth.

Further questions were asked on the quality of the water they were using at household level and the results are presented in Table 4.4 .

Table 4.4. Distribution of the respondents on quality of water

\begin{tabular}{lll}
\hline Description & Frequency & Percentage \\
\hline Potable and safe & 14 & 7.2 \\
Moderately safe & 69 & 35.4 \\
Fair Quality & 79 & 35.9 \\
Poor Quality & 42 & 21.5 \\
Total & 195 & 100 \\
\hline
\end{tabular}

From the above presentation, majority of the respondents $35.9 \%$ reported the water to be moderately safe and $35.4 \%$ 
reported the water to be of fair quality. However, $21.5 \%$ of the respondents cited the water to be of poor quality for human beings to consume while $7.2 \%$ of the respondents reported the water to be potable.

\subsubsection{Water Affordability}

Water affordability was categorized into cost per 20litre jerican, respondents' view of the rate charged and its causes.

Table 4.5. Respondents perception of the cost of water

\begin{tabular}{lll}
\hline Description & Frequency & Percentage \\
\hline Very Expensive & 49 & 25.1 \\
Expensive & 122 & 62.6 \\
Normal & 18 & 9.2 \\
Not expensive & 6 & 3.1 \\
Total & 195 & 100 \\
\hline
\end{tabular}

From the presentation, majority of the respondents $62.6 \%$ reported that the cost of water was expensive while $25.1 \%$ of the respondents reported the water to be very expensive. $9.2 \%$ and $3.1 \%$ of the respondents reported the cost of water to be normal and not expensive respectively.

\subsubsection{Distance and Time taken to Water Points}

The study was also interested still on looking at water access to find the relation between distance and time taken to water points as presented in distance round trip, time taken to collect water in dry and wet seasons. The study looked at the distances covered to fetch water by respondents and presented in Table 4.6.

Table 4.6. Distances covered round trip to water points.

\begin{tabular}{lll}
\hline Description & Frequency & Percentage \\
\hline Less than $2 \mathrm{Km}$ & 52 & 26.7 \\
Between $2-5 \mathrm{Km}$ & 91 & 46.7 \\
Between $5-10 \mathrm{Km}$ & 41 & 21.0 \\
More than $10 \mathrm{~km}$ & 11 & 5.6 \\
Total & 195 & 100 \\
\hline
\end{tabular}

From the above presentation, majority of the respondents, $46.7 \%$ covered between $2-5$ kilomtres to fetch water, this was followed closely with $26.7 \%$ fetching water in less than 2 kilomtres, $21.0 \%$ fetching water between 5-10 kilomtres and $5.6 \%$ fetching water in more than 10 kilometres.

The respondents were also asked to state the time they spend to fetch water in dry season as presented in Table 4.7.

Table 4.7. Time spend to fetch water in Dry Season

\begin{tabular}{lll}
\hline Description & Frequency & Percentage \\
\hline Less than 30 mins & 34 & 17.4 \\
Between 30-60 mins & 53 & 27.2 \\
More than 60 mins & 108 & 55.4 \\
Total & 195 & 100 \\
\hline
\end{tabular}

From the presentation above, majority of the respondents $55.4 \%$ spend more than 1 hour to fetch water while $27.2 \%$ and $17.4 \%$ spend between 30-60 minutes and less than 30 minutes to fetch water.

Table 4.8. Distribution of Respondents by presence of rainwater harvesting

\begin{tabular}{lll}
\hline Description & Frequency & Percentage \\
\hline YES & 125 & 64.1 \\
NO & 70 & 35.9 \\
Total & 195 & 100 \\
\hline
\end{tabular}

From the above presentation, majority of respondents $64.1 \%$ practice rain water harvesting while $35 \%$ of the respondents do not.

\subsection{Management of Water Projects}

The second objective of the study was to determine how management of water projects impact in sustainable rural livelihoods. Here who manages, gender composition of management committees and decision making of women, operation and maintenance, ownership and challenges faced by water projects are presented. Respondents were asked questions relating to the management of water projects in order to ascertain who manages water projects in the study area as presented in Table 4.9.

Table 4.9. Management of water Projects

\begin{tabular}{lll}
\hline Description & Frequency & Percentage \\
\hline Water committees & 164 & 84.1 \\
NGOs & 3 & 1.5 \\
Government & 8 & 4.1 \\
Church & 1 & 0.5 \\
Village committees & 19 & 9.7 \\
Total & 195 & 100 \\
\hline
\end{tabular}

From the presentation above, majority of the respondents $84.1 \%$ reported that water committees were managing water projects while those managed by village committees comprised of $9.7 \%$ while government, NGOs and church managed $4.1 \%, 1.5 \%$ and $0.5 \%$ respectively.

\subsection{Composition of Management Committees}

Respondents were asked questions relating to the composition of the management of water projects as presented in Table 4.10.

Table 4.10. Composition of the Management of water Projects

\begin{tabular}{lll}
\hline Description & Frequency & Percentage \\
\hline Both Men and Women & 98 & 51.6 \\
Men only & 50 & 26.4 \\
More men and few women & 40 & 21.1 \\
More women and few men & 2 & 1.1 \\
Total & 190 & 100 \\
\hline
\end{tabular}

From the presentation above, majority of the respondents 
$51.6 \%$ said that in the management there were both men and women, while $26.4 \%$ reported that there were only men in the committees. However, $21.0 \%$ reported that there were more men and few women in the committees and $1.0 \%$ reported that there were more women and few men in the committees.

\subsection{Operation and Maintenance of Water Project}

This section present issues on operation and maintenance of water projects in the study area.

Questions were posed to the respondents on who operates and maintains water projects in the community and was presented in Table 4.11.

Table 4.11. Personnel carrying out operations and maintenance of Water Projects

\begin{tabular}{lll}
\hline Description & Frequency & Percentage \\
\hline Trained Technicians & 17 & 8.7 \\
Untrained Technicians & 70 & 55.8 \\
Untrained water committees & 100 & 12.6 \\
Trained Water Committees & 8 & 5.3 \\
Total & 195 & 100 \\
\hline
\end{tabular}

From the above presentation, majority of the respondents $55.8 \%$ reported that operations are done by untrained technicians while untrained water committees, trained technicians and trained water committees accounted for $12.6 \% 8.7 \%$ and $5.3 \%$ respectively.

\subsection{Socio-Economic Factors of Water Project}

The third objective of the study was to determine how socio-economic factors of water projects impact in sustainable rural livelihoods. Here discussions are presented based on water scarcity and its effects on the education of the child and mitigation measures by families to counter water scarcity.

\subsubsection{Water Uses}

Table 4.12 shows how the respondents utilize their water in household

Table 4.12. Water Use by Respondents

\begin{tabular}{lll}
\hline Description & Freq & Percentage \\
\hline Washing clothes, hygiene & 57 & 29.2 \\
Cleaning & 45 & 23.1 \\
Drinking & 92 & 47.2 \\
Kitchen gardens & 1 & 0.5 \\
Total & 195 & 100 \\
\hline
\end{tabular}

Majority of the respondents, $47.2 \%$ rely the water from the water sources for drinking while $29.2 \%, 23.1 \%$ and $0.5 \%$ rely for washing clothes and hygiene, cleaning and kitchen gardens respectively.

\subsubsection{Water Scarcity and Children}

Here the respondents were asked questions relating to the effects of water scarcity on children lives as presented in Table 4.26. Of the 195 respondents interviewed, 170 representing
$87.2 \%$ agreed that children lives are affected by water scarcity whereas $12.8 \%$ disagreed.

Table 4.13. Water Scarcity and Effects on Children

\begin{tabular}{lll}
\hline Description & Frequency & Percentage \\
\hline Don't attend school & 56 & 32.9 \\
Walk long distances to fetch water & 112 & 65.9 \\
Employed to carry water & 2 & 1.2 \\
Total & 170 & 100 \\
\hline
\end{tabular}

From the presentation, majority of the respondents $65.9 \%$ reported that children walk long distances to fetch water, $32.9 \%$ reported that children do not attend school at all as their parents leave them at home to look for this commodity or the children leave school to look for the water with their parents. $1.2 \%$ of the respondents reported that children are employed to carry water.

\subsubsection{Household Coping Strategies during Water Scarcity}

Here the respondents were asked questions relating to the effects of water scarcity on household as presented in Table 4.14 .

Table 4.14. Coping Strategies during Water Scarcity

\begin{tabular}{lll}
\hline Description & Frequency & Percentage \\
\hline $\begin{array}{l}\text { Sale of chicken and eggs } \\
\text { Sale of farm produce (beans, maize, }\end{array}$ & 52 & 26.7 \\
$\begin{array}{l}\text { potatoes) } \\
\text { Sale of small livestock (goats, sheep) }\end{array}$ & 33 & 44.6 \\
$\begin{array}{l}\text { Sale of large livestock Cows, bulls) } \\
\text { Sale of household items (tables, beds, }\end{array}$ & 1 & 16.9 \\
kitchen items) & 22 & 0.5 \\
Total & 170 & 11.3 \\
\hline
\end{tabular}

From the presentation, majority of respondents $44.6 \%$ reported ale of farm produce (beans, maize, potatoes) to purchase water, this was followed by sale of chicken and eggs, sale of small livestock (goats and sheep), sale of household items (tables, beds, kitchen items) and sale of large livestock (cow and bulls) at 26.7\%, 16.9\%, 11.3\% and $0.5 \%$ respectively.

\section{Discussion}

With the income that the community members earn from agriculture and other sources of income, it may become difficult to meet family needs. An example would be a family of 4 persons requires 60 litres per person per day which translates to 1800 litres purchasing water at Kshs 5 will require Kshs 9000 each month to meet water costs which may not happen because the family has other requirements. This makes the family to resort to other cheap water which may compromise water quality as well health of the household, thereby, increasing their chances of vulnerability.

Available water to the communities remains unsafe forcing families to incur extra expense to not only pay for water bills but also pay health charges. This coupled with several families 
living below Kshs 5000 monthly may make them susceptible to other forms of behaviour that may negate morality and modernization. A low target of households harvesting rain water still is a challenge as most communities have not appreciated harvesting run offs for agriculture. Most of the water in unprotected pans are shared with domestic animals and wild animals. Piped water into dwelling was at $2.6 \%$ compared to $7.6 \%$ for the country Kenya National Human Development Report KNHD), (2006). This is far much below and resources need to be harnessed to improve on the findings

Water quality has an impact on rural livelihoods. Water sources impede on the health status of households thereby limits their opportunities in meeting their daily opportunities and income when they fall sick after consuming water of poor quality. Of great concern is the percentage of community members suffering from diseases that can be prevented by using safe water. Bartam, 2005 and Pruss-Ustan (2008) agrees with this fact. UNDP, (2006) report also concurs with the findings that diarrhoea remains the killer diseases and is associated with unsafe water.

Water are sold at an exorbitant prices this is because of high operations costs as most of the people charged with the responsibilities of water projects are untrained. Another aspect is that most of the water projects are mismanaged and therefore this is pushed to the consumers of water. Presence of middle men/persons or cartels also poses a challenge on the pricing of water thereby impeding on the purchasing power of families and individuals.

On women and girls walking long distances to fetch water, the study found out that women carry water in their backs and therefore may need to make more trips to access the commodity. An example would be a woman needs about 100 litres for the household; this may force her to make five trips each day translating to five hours spent. This compares favourably with what UN, (2000) found out.

On management of water projects, Operations and Maintenance (O\&M) remains with people who have not been trained, increasing the chances of communities to be secluded through marginalization and increase in water prices. Community participation needs to be improved to check on accountability of the assigned persons to take care of the community interest without affecting their lives. This finding concurs with UNDP-World Bank, (2008).

In order to cope with water scarcity, households may sell their assets to offset pending water bills. This may limit their assets within the household level and render them vulnerable.

With reference to Table 4.5 on income levels, majority of the respondents earning less than Kshs 5000 per month may not afford the water and therefore resort into water of poor quality.

\section{Conclusions}

The purpose of this study was to assess the impact of water access, water management and socio-economic factors on sustainable Rural Livelihoods in Elementaita Division. The following conclusions were made from the results of the study.
The quality of water has an impact on the income and health status of children, families and community members. Individuals spend their meagre resources when they fall sick to treat themselves owing to a preventable cause of poor water quality in the community.

Distances to water sources are far thereby many household spend several hours looking for the precious commodity. These hours spend would be used to carry out other chores and activities that would increase on the income levels of the families.

\section{Recommendations}

The following recommendations were made in order to reduce effects of water access on sustainable rural livelihoods.

There is need to train water committees on proper management of water in the community. The community members also need to be sensitized on the need to put their water project committees to task over cases of corruption and cartels. This could be done through government efforts of strengthening water Users Associations through implementation of the Water Act 2001.

There is need to sensitize communities not to interfere with the education of their children during dry seasons as majority were engaged out of school. This could be done in consultation with Ministry of Gender, Children and Social Development. Of great concern is child labour that the Ministry needs to advocate to the very end.

Government of Kenya, through ministry of Water and Irrigation to increase levels of awareness of Rain Water Harvesting to Improve of the Quality of water at household level.

Ministry of Water and Irrigation and other partners to put measures in place to train community members and committees on effective operations and maintenance of water projects this will reduce challenges faced by communities.

The following areas are suggested for further study: To determine the impact of water scarcity of household purchasing power and to determine the impact of training of water committees on operation and maintenance.

\section{References}

[1] Anderson, J. and Poole, M. (2001) Assignment and thesis writing $.4^{\text {th }}$ Ed. John Wiley and Sons. Brisbane

[2] Ashley, Caroline and Diana Carney. (1999). Sustainabl Livelihoods: Lessons from Early Ex perience. DFID, London.

[3] Asian Development Bank (ADB) (2010) Impact of Rural Water Supply and Sanitation. Independ ent Eval tion Department, Pakistan.

[4] Babbie, E. (1992). The Practice of Social Research (6 ed).: Wadsworth Publishing Company. Belmont

[5] Bartram, J. K. Lewis, R. Lenton and A. Wright (2005).The Millennium Project: Focusing on Im proved water and sanitation for health. Lancet 
[6] Bauman, E. (2005) Community Manager water supplies in Africa.

[7] Bennett, N. (2010). Sustainable Livelihoods from Theory to Conservation Practice: An Extended Annotate Bibliography for Prospective Application of Livel hoods. Victoria, Canada.

[8] Best, J. W., and Khan, V. (2009) Research in Education. $7^{\text {th }}$ Edition, Prentice Hall, New Delhi: India.

[9] Carlevaro F, and Gonzalez C .(2011). Costing improved water supply systems for low-income commun ties: a practical manual. CDROM. World Health O ganiztion, Geneva.

[10] Carney, D. (1998). Sustainable Rural Livelihoods: What Contribution can we make?. DFID. London.

[11] Carney, Diana. (1999). Approaches to Sustainable Livel hoods for the Rural Poor. ODI Poverty. Briefing No. 2, ODI, London.

[12] Castillo, J.J. (2009). Simple Random Sampling. http://www.experiment-resources.com/simple- $\quad r$ dom-sampling.html Retrieved 18 Apr. 2012 from E periment Resources:

[13] Chambers, R. and Gordon C. (1992). Sustainable Livel hoods: Practical concepts for the $21^{\text {st }}$ Century. IDS Discussion Paper 296, IDS, Brighton, UK.

[14] Chambers, R. (2007). Poverty and Livelihoods: Whose R ality Counts? IDS discussion Pa per 347,

[15] Cochran, W. G. (1963). Sampling Techniques, $2^{\text {nd }}$ Ed., John Wiley and Sons, Inc. New York:

[16] Cooper, D. R. and Schindler, P. S. 2001. Business Research Methods $\left(7^{\text {th }}\right.$ ed.). McGraw- Hill Irwin. Boston

[17] Deepesh, M. (2004). Planning and design of cost-effective water harvesting structures

[18] Dercon, S., and Krishnan P. (2000). In sickness and I health: risk sharing within households in rural Ethiopia. Journal of Political Economy, 108: 688-727.

[19] DFID. (1999). Sustainable livelihoods guidance sheets. DFID. London,

[20] DFID. (1999). Sustainable Livelihood. DFID, London,

[21] DFID, (2002) Sustainable Livelihood. DFID, London

[22] DFID, (2010). Sustainable Livelihood. DFID, London

[23] DFID, (2011). Sustainable Livelihood. DFID, London

[24] Ellis, F. (2000). The determinants of rural livelihood dive sification in developing countries. Journal of Agr cultural Economics, 51: 289-302.

[25] El-Sadek, A. (2011). Virtual water: An effective mechanism for integrated water resources man a ment.doi:10.4236/as2011.23033 for efficient utiliz tion of scarce water resources in semi-arid regions of Rajasthan, India. Water Resources Management, 18: 219-235.

[26] Gay,L.R.(1981) Education Research: Competencies for Analysis and Application. Charles E. Mairill Pu lishing Co. A. Bell and Howell Co, Toronto and Lo don.

[27] Gowing, J.W. (2003). Food security for sub-Saharan Africa: does water scarcity limit the op tions? Land Use an Water Research.

[28] Grey-Gardner, R. (2008). Remote Community Water Ma agement-Report 27. Desert

[29] Grey-Gardner, R. (2008). The Water Handbook. Desert Knowledge CRC, Alice Springs, Groundwater for health: managing the quality of drinking-water sources. International Water Association Publising, 3-19. London

[30] Haysom, A. (2006) A study on Factors Affecting sustain bility of rural water supply. Cranfield university.

[31] Howard G. (2006). Groundwater and public health. In: Schmoll O. eds. Protecting Knowledge CRC, Alice Springs, Australia.

[32] Human Development Report (HDR) (2006) Beyond Water Scarcity: Power, poverty and the global water cr sis. UNDP. New York.

[33] Hunt N and Tyrell, (2001) Probability Sampling Technique. Covenrty University.

[34] IDRC, (1996). Grassroots indicators for desertification. E perience and perspectives from Eastern and Sout ern Africa. Ottawa, Canada.

[35] Isaac, S. and Michael W.N. (1977) Handbook in Research and Evaluation ( ${ }^{r d}$ ed.).:EdITS. San Diego

[36] Joppe, M. (2000). The Research Process. IDS Press, Lo don, UK.

[37] Kenya National Human Development (KNHD) (2006)

[38] KIHBS (2006) Basic Report on Well-being in Kenya. Ke ya Bureau Of Statistics. Nairobi.

[39] Kirk, J., and Miller, M.L. (1986). Reliability and Validity in Qualitative Research. Sage Publica tions. Beverly Hills.

[40] KNWRMS (2006) Water: A Shared Responsibility.

[41] Kratz, L. 2001. An Introduction: The Sustainable Livel hood Approach to Poverty

[42] Krueger, (1988) Focus Groups: A Practical Guide for A plied Research. London: Sage

[43] Lipton, M. and Moore, M. (1972). The Methodology of V ilage Studies in Less Developed coun tries. IDS, University of Sussex. Brighton

[44] Millennium Community Development Initiatives, (2010): Community Guide to Water Act 2002. Nairobi Kenya.

[45] Mehrens, W.A. and Lehmann, I.J. (1987). Using Standar ized tests in Education. Longman. New York.

[46] Mehta, M. and Ondari, J. (2004) "Sector finance and $r$ source flows for Water supply: A pilot application for Kenya”, Water and Sanitation program for Africa. Nairobi.

[47] Montogomery, D.R. (2007). Soil Erosion and Agricultural Sustainability California press US.

[48] Moriarty, P., Butterworth, J., and Koppen B.V.,

[49] (2004): Water, Poverty and Productive Uses of Water at the Household Level. Beyond Domestic IRC International Water and Sanitation 
[50] Morse, S., McNamara, N. and Acholo, M. (2009). Sustai able Livelihood Approach: A critical analysis of theory and practice. University of Reading, London, UK.

[51] Mugenda, O. M. and Mugenda, A. G. (1999) Researc Methods: Quantitative and Qualitative Approaches. Acts Press. Nairobi.

[52] Mugenda , O. M. and Mugenda, A. G. (2003) Researc Methods Quantitative and Qualitative Approaches. Acts Press. Nairobi.

[53] Nicol, (2000) 'Adopting a Sustainable Livelihoods A proach to Water Projects: Implications for Policy and Practice', Working Paper, No.133, ODI. London.

[54] OCHA, (2010) Water Scaricty and Humanitarian Action: Key Emerging trends and challenges. OCHA, Po icy Development and Studies Branch

[55] Onjala, J.O. (2002), Managing water scarcity in Kenya: Industrial responses to tariffs and regu latory e forcement. Roskilde University (PhD thesis)

[56] Pacey A, and Cullis A (1986). Rainwater harvesting: the collection of rainfall and runoff in rural areas. I termediate Technology Publications. London.

[57] Petersen E., and Gould, J. (1999). Rainwater catchments systems for domestic supply: design, con struction and implementation. Intermediate Technology Develo ment Group Publishing. London.
[58] Pruess-Uestuen, A., Bos, R., Gore, F. and Bartam, J. (2008). Safer Water, Better Health. WHO. Geneva:

[59] Scoones, I. (2009). Livelihoods Perspectives and Rural D velopment. Journal of Peasant Studies, 36 (1)171-196.

[60] Scoons, I. (1998). Sustainable Rural Livelihoods: A Framework for Analysis. IDS, Working paper 72, IDS, Brighton, UK.

[61] Sen, A. (1987). The Standard of Living. Cambridge Unive sity Press. Cambridge.

[62] SIWI,(2002). Balancing Competing Water Uses-Present status and New Prospects, Stockholm. International Water Institute (SIWI), Stockholm, Sweden.

[63] Smet J (2005). WELL fact sheet: domestic rainwater ha vesting. Waterlines, 24: 13-20.

[64] Solesbury, W. (2003). Sustainable Livelihoods: A Case of the Evolution of DFID Policy. Over seas Development Institute, London.

[65] Swallow, B, Onyango, L., Dick, R.M., and Holl, N,. (2005) Dynamics of Poverty, livelihoods and property rights in the Lower Nyando Basin of Kenya. Joha nesburg. South Africa.

[66] Swift, J. (1989). Why are rural people vulnerable to fa ine? IDS Bulletin, 20(2), 41-49. 